\title{
Implementation of Scientific Approaches in Craft and Entrepreneurship Learning
}

\author{
$1^{\text {st }}$ Amir Fatah ${ }^{1}, 2^{\text {nd }}$ Dinn Wahyudin ${ }^{2}, 3^{\text {rd }} \operatorname{Rusman}^{3}$ \\ amir.fatah3@gmail.com ${ }^{1}$,dinn-wahyudin@upi.edu ${ }^{2}$,rusman821971@gmail.com ${ }^{3}$ \\ School of Postgraduate Indonesia University of Education, Indonesia ${ }^{123}$
}

\begin{abstract}
Entrepreneurship education has been considered as one of the important factors to grow and develop passion, soul and entrepreneurial behavior among the younger generation. Attitudes, behavior and knowledge about entrepreneurship will form the tendency to open new businesses in the future. Related to the influence of entrepreneurship education, it is necessary to have an understanding of how to develop and encourage the birth of potential young entrepreneurs while in school. Realizing this, the government through the Ministry of Education and Culture made a curriculum change that included craft and entrepreneurship subjects (crafts, engineering, processing and cultivation) in primary and secondary education. The new curriculum also encourages all learning to use a scientific approach. However, craft education and entrepreneurship in Indonesia have not fully contributed positively to the intelligence and welfare of the nation, whereas the potential of entrepreneurship in Indonesia is very large, especially when viewed from the data of the number of small and medium businesses that exist. This article provides an overview of how the implementation of craft and entrepreneurship learning (crafts, engineering, processing and cultivation) with scientific approaches carried out by teachers according to student perception.
\end{abstract}

Keywords: Scientific, Approaches, Craft, Entrepreneurship, Learning

\section{Introduction}

The decision to enter craft and entrepreneurship subjects as a mandatory lesson shows an old paradigm shift which states that entrepreneurship is an innate talent, to a new paradigm that entrepreneurship is a science that can be learned. Entrepreneurship education is education that applies principles and methodologies towards internalizing the values of entrepreneurship in students through an integrated curriculum [1]. Entrepreneurship education can shape entrepreneurship by increasing knowledge about business and forming psychological attributes such as self-confidence, self-esteem and self-efficacy [2].Entrepreneurship education can be an agent of extraordinary change in all sectors. Not everyone must be an entrepreneur to feel the benefits of entrepreneurial education, but everyone must be entrepreneurial [3].

Growing the entrepreneurial spirit of high school graduates needs to be directed and supported so that they are not only oriented as job seekers but can and are ready to become job 
creators, because students are expected to be educated young entrepreneurs who are able to pioneer their own business [4]. Compared to other countries, the development of entrepreneurship in Indonesia is still very low, which is under $2 \%$. In comparison, entrepreneurship in the United States reaches 11 percent of the total population, Singapore as much as 7 percent, and Malaysia as much as 5 percent Error! Reference source not found.[5]. So, the development of human resources with entrepreneurial competence in the younger generation is appropriate and relevant for students to become entrepreneurs and create jobs.

The influence of entrepreneurship education has been considered as one of the important factors to foster and develop entrepreneurial passion, soul and behavior among the younger generation Error! Reference source not found.[6]. Related to the influence of entrepreneurship education, it is necessary to have an understanding of how to develop and encourage the birth of prospective young entrepreneurs when they go to school Error! Reference source not found.[7]. Previous studies have suggested that students' entrepreneurial desires are a source of the birth of future entrepreneurs [8]. Their attitude, behavior and knowledge about entrepreneurship will shape their tendency to open new businesses in the future Error! Reference source not found.

One of the factors driving the growth of entrepreneurship in a country lies in the role of schools through the implementation of entrepreneurial education. The school is responsible for educating and providing entrepreneurial skills to its graduates and provides motivation to dare to choose entrepreneurship as a career. The school needs to apply concrete entrepreneurial learning patterns based on empirical input to equip students with meaningful knowledge in order to encourage enthusiasm for entrepreneurship Error! Reference source not found.[9].

However, craft education and entrepreneurship in Indonesia have not fully contributed positively to the intelligence and welfare of the nation, whereas the potential of entrepreneurship in Indonesia is very large, especially when viewed from the data of the number of small and medium businesses that exist. In Indonesia until 2017 there were 48.9 million Small and Medium Enterprises (SMEs) which absorbed about $80 \%$ of the workforce and contributed $62 \%$ to GDP (excluding oil and gas). These data provide an overview of how much entrepreneurial activity (as reflected in the number of SMEs) in Indonesia. But this huge potential has not been used optimally, there are still many problems of unemployment and the poor and the income of the Indonesian people below the poverty line. February 2017 is the number of open unemployment of 7.02 million people, which is dominated by high school graduates by 1.55 million[1].

A number of empirical research results show that formal education fails to achieve the target of entrepreneurial education. The contribution of vocational education in this problem is questioned by many parties, because many graduates do not meet the qualifications needed by the user sector and are not ready to become entrepreneurs. The results of research Error! Reference source not found.[10] show that formal education does not have a significant influence on the formation of character and entrepreneurial attitudes for students. That formal education is unable to encourage entrepreneurship of its graduates; the school is limited to preparing graduates for knowledge about the company, and preparing mentally to find work, rather than suppressing students' creativity and entrepreneurship.

Learning is not only limited to absorbing information, more than that learning is a process that is more related to socialization so that teachers are needed who can guide and support each learning system Error! Reference source not found.[11]. An entrepreneurial teacher should be able to transfer entrepreneurial attitudes and the ability to build student personality characteristics that are appropriate and not directly related to the business context (creativity, 
risk taking and responsibility) and specific training on how to make new business [2]. The success of entrepreneurial education is strongly influenced by the role of the teacher. Entrepreneurship teachers are required to be able to instill entrepreneurial attitudes and characters for their students Error! Reference source not found.

The success of entrepreneurship education is the same as choosing and promoting teachers who are able to encourage their students to get the full activities of the appropriate experience. The fact shows that most secondary school teachers have not been trained in entrepreneurship, and are less aware of the right approach to teaching entrepreneurship. Considering that teachers have a central role in the success of entrepreneurial education, the standardization of entrepreneurship teachers in secondary schools is an important and urgent matter to do. in some countries, there have also been variations in entrepreneurship education including the development of various models (inside and outside education) by developing all related elements[2]

This study provides an overview of the scientific approach used by teachers in the implementation of Craft and Entrepreneurship learning in secondary schools based on student perceptions.

\section{Theoretical}

\subsection{Scope of Crafts and Entrepreneurship Subjects}

Crafts and Entrepreneurship are basically not new subjects because in the 2006 Curriculum the name of these subjects is Skills [3]. Broadly speaking, the principle between Skills and Crafts subjects is the same, the difference in the Crafts has the purpose and foundation of educational background so as to foster sensitivity to the products of local wisdom, technological development and the building of an entrepreneurial spirit. While from its scope, the Crafts and Entrepreneurship subjects cover four aspects, namely crafts, engineering, cultivation and processing .

The craft aspect is related to the work of the hand which results are objects to fulfill the demands of satisfaction of view: aesthetics - ergonomics, with cultural symbols, the needs of ceremony and belief (theory of magic and relligy), and functional objects that are associated with the value of education in the manufacturing procedure.

Engineering aspects related to several capabilities: designing, reconstructing and making product objects that are useful in everyday life with a problem-solving approach. This scope requires thought unity and hand dexterity to make the arrangement lead to: creative thinking, practical, effective, precise and efficient and predictive thinking. The aspect of cultivation originates in cultivation, which is a work that tries to add, grow, and realize things or living things to be larger / grow, and multiply, multiply. The benefits of this cultivation technology education are feeling coaching, coaching the ability to understand growth and unite with nature (ecosystem) to be students who think systematically based on the potential of local wisdom. The processing aspect means making, creating basic ingredients into finished product objects, so that they can be used. In principle, processing work is converting raw materials into finished products that have added value through management techniques such as: mixing, preserving, and modifying. The benefits of educational processing technology for the development of students' personalities are: sense training that can be correlated in daily life, systematically combined with thoughts and crafts. 


\subsection{Scientific Approach in Learning}

The scientific approach refers to the technique of investigating phenomena, acquiring new knowledge, integrating prior knowledge with methods of inquiry based on objective evidence through observation or experiment, then formulating and testing hypotheses [3]. The science learning process emphasizes to provide a direct experience to understand the natural problems surrounding it scientifically. Science can be considered as a means to develop certain attitudes and values such as religious values, objectivity, order, openness, practical and economic values, and ethics and aesthetics. The Scientific Approach can give students the freedom to explore, but at the same time direct them to the scientific process to solve problems and also get the same results, learning with a scientific approach can improve students' scientific skills such as activity and performance in the lab, report on making and presentation skills.

The Scientific Approach is intended to provide understanding to students that information can be obtained from anywhere and at any time not only from the teacher. The teacher is a facilitator while students are learning subjects that need to be actively involved in the learning process. Learning with scientific approaches such as experimental activities and demonstrations can improve students' scientific attitudes and analytical skills. The criteria for scientific approach to learning according to the Ministry of Education and Culture [3] are based on facts, free from misconceptions, directing critical, hypothetical, analytical thinking so that they can understand, solve problems, apply learning material, develop rational and objective mindsets. While science-based learning according has the characteristics of students involved actively doing activities and trained learning by doing so that they can make decisions independently and teachers use a varied learning model.

The 2013 curriculum uses a saitifik approach because this approach is considered appropriate to develop students' attitudes, knowledge, and skills. Learning with the Scientific Approach is a learning process designed in such a way that students actively construct concepts, laws or principles through observing stages (to identify or find problems), formulate problems, propose or formulate hypotheses, collect data with various techniques, analyze data, draw conclusions and communicate concepts, laws or principles that are "discovered" [12]. The Scientific Approach is intended to provide understanding to students in knowing, understanding various materials using the scientific approach. Learning is directed to encourage students to find out from various sources through observation, not just given by the teacher. The purpose of this approach is that students are able to solve problems that will be faced well in their daily lives[13] .

The steps of the Scientific Approach in the learning process are observing, asking questions, gathering information / searching, reasoning / associating, and communicating :

Table 1. Description of Activities and Roles of Teachers in Learning Activities using the Scientific Approach[3]

\begin{tabular}{|l|l|l|}
\hline $\begin{array}{l}\text { Learning } \\
\text { Steps }\end{array}$ & \multicolumn{1}{|c|}{$\begin{array}{c}\text { Description of } \\
\text { activities }\end{array}$} & \multicolumn{1}{|c|}{ Teacher's role } \\
\hline Observing & $\begin{array}{l}\text { Observe with the senses (reading, } \\
\text { listening, seeing, watching, etc.) } \\
\text { with or without tools. }\end{array}$ & $\begin{array}{l}\text { Facilitate students to } \\
\text { observe. }\end{array}$ \\
\hline $\begin{array}{l}\text { Asking/ } \\
\text { questions }\end{array}$ & $\begin{array}{c}\text { Make and ask questions, ask quFacilitate students to do } \\
\text { information that has not been und the questioning process } \\
\text { information that you want to know }\end{array}$ \\
\hline Collect & Exploring, trying, discussing, & Facilitate students to \\
\hline
\end{tabular}




\begin{tabular}{|l|l|l|}
\hline information/ & $\begin{array}{l}\text { demonstrating, imitating forms, } \\
\text { conducting experiments, reading } \\
\text { sources other than textbooks, } \\
\text { collecting data from resource } \\
\text { persons through questionnaires, } \\
\text { interviews, and modifying / adding } \\
\text { / expanding right. }\end{array}$ & $\begin{array}{l}\text { carry out the process of } \\
\text { gathering information / } \\
\text { trying. }\end{array}$ \\
\hline $\begin{array}{l}\text { Reason or } \\
\text { associate }\end{array}$ & $\begin{array}{l}\text { Processing the information that } \\
\text { has been collected, analyzing } \\
\text { data in the form of categorizing, } \\
\text { associating or connecting related } \\
\text { phenomena / information in } \\
\text { order to find a pattern, and } \\
\text { conclude }\end{array}$ & $\begin{array}{l}\text { Facilitate students to } \\
\text { make the process of } \\
\text { reasoning / associating }\end{array}$ \\
\hline Communicate & $\begin{array}{l}\text { Presenting reports in the form of } \\
\text { charts, diagrams, or graphs, } \\
\text { compiling written reports, and } \\
\text { presenting reports covering the } \\
\text { process, results and conclusions } \\
\text { orally. }\end{array}$ & $\begin{array}{l}\text { Facilitate students to } \\
\text { carry out } \\
\text { process } \\
\text { communicating. }\end{array}$ \\
the \\
\hline
\end{tabular}

\section{Method and Data Collecting}

The subjects in this study are teachers who have more than five years of teaching experience and have been certified as professional teachers, as well as students in class X with the consideration that all students from all schools have the opportunity to become subjects, because some schools apply the new 2013 curriculum in 2017 .The object of the research is the process of learning the Crafts and Entrepreneurship held by State Secondary Schools throughout Kulon Progo Regency. State Secondary Schools in Kulon Progo Regency are 11 schools spread in various locations which can be broadly grouped into four groups with different characteristics, namely urban, rural, mountainous and coastal.

The research data was collected using a list of statements developed by researchers totaling 14 items using a 4-level Likert scale supported by in-depth interviews with several representative students of each class. The construct validity test is carried out by asking the experts in the field of learning and measurement. While empirical validity is carried out by instrument testing. The results of the instrument testing with the number of responses $n=30$ found the item validity of the statement ranged from 0.465 to 0.800 and the alpha reliability coefficient was 0.98 .

\section{Resultts and Discussion}

Research results The implementation of craft learning and entrepreneurship (crafts, engineering, processing and cultivation) in scientific approaches can be explained in Table 2 . The following: 
Table 2. Implementation of Scientific Approach

\begin{tabular}{|l|l|c|}
\hline No & Acyivity of Scientific Approach & Score \\
\hline 1 & Observe & 2.47 \\
\hline 2 & Question & 2.51 \\
\hline 3 & Eksperiment & 1.96 \\
\hline 4 & Assosiating & 1.76 \\
\hline 5 & communicate & 2.79 \\
\hline & & Mean \\
\hline
\end{tabular}

Based on Table 2. it can be seen that the implementation of scientific approaches in craft learning and entrepreneurship in general is still in the low category, except at the stage of communicating that has reached a high category.

In the observation phase, it is known that the opportunity given by the teacher to make observations either through reading, listening, or seeing the students rate $20.1 \%$ is very low; $28.6 \%$ low; $40.2 \%$ high and only $11.1 \%$ is very high. Likewise, the suitability of the observation guidelines given by the teacher with the object being observed, students rated $39.7 \%$ felt very low; $30.7 \%$ low; $24.9 \%$ high and only $4.8 \%$ very high. To benefit the observation procedure given by the teacher in collecting observable object data, students rated $8.5 \%$ felt very low; $18.5 \%$ low; $33.3 \%$ high and $39.7 \%$ very high.

The questioning stage is known that the teacher's ability to encourage students to ask according to the topics discussed is that students rated $21.2 \%$ as very low; $59.3 \%$ low; $16.9 \%$ high and only $2.6 \%$ very high. Likewise the ability of teachers to encourage students to ask questions clearly, students rated $9.5 \%$ felt low; $76.2 \%$ high and only $14.3 \%$ very high. For teacher's attention to students' responses or answers, students rated $8.5 \%$ as very low; $45.5 \%$ low; $37.6 \%$ high and $8.5 \%$ very high.

The stage of gathering information or experiments is known that the opportunity given by the teacher to gather information from various sources outside the classroom or outside of school then the students rated $54.5 \%$ felt very low; $36.5 \%$ low; $8.5 \%$ high and only $0.5 \%$ very high. Likewise the opportunity given by the teacher to conduct direct experiments in accordance with the topics discussed, students rated $24.3 \%$ felt very low; $58.2 \%$ high; $15.3 \%$ high and only $2.1 \%$ very high. For the readiness of the teacher to do coaching during the practice, the students rated $15.3 \%$ as very low; $45.5 \%$ low; $25.4 \%$ high and $13.8 \%$ very high.

The stage of associating or processing information is known that the teacher's habit of repeating so that the desired behavior becomes a habit, the student considers $9.5 \%$ to be very low; $41.3 \%$ low; $38.1 \%$ high and only $11.1 \%$ very high. Likewise, the evaluation carried out by the teacher is based on real or authentic behavior, students think $7.4 \%$ is very low; $29.6 \%$ high; $42.3 \%$ high and $20.6 \%$ very high. 
The stage of communicating is known that the opportunity for students to argue according to the topic discussed is that students assess $1.1 \%$ as very low; $38.6 \%$ low; $46.6 \%$ high and $13.8 \%$ very high. Likewise teacher support to build an attitude of openness among students in terms of opinion, students rated $5.8 \%$ felt very low; $29.1 \%$ high; $50.8 \%$ high and $14.3 \%$ very high. For the support of teachers training politeness in speaking to arouse the ability to empathize with each other, students rated $8.5 \%$ felt very low; $20.6 \%$ low; $40.7 \%$ high and $30.2 \%$ very high.

The results of the study show that the implementation of a scientific approach in craft learning and entrepreneurship needs to be improved. This is because craft education and entrepreneurship are expected to increase the interest and motivation of students and graduates of public secondary schools, where up to now high school graduates are still job seekers and not creating jobs. Meanwhile, to continue to the tertiary level, currently the ratio of the number of secondary school graduates and opportunities in universities is still not balanced.

\section{Conclusion}

The implementation of scientific approaches in craft learning and entrepreneurship (crafts, engineering, processing and cultivation) is still in a low level. Capacity building and understanding in the implementation of scientific approaches needs to be improved. Teacher training about the learning process needs to be done so that understanding of learning strategies, learning approaches, learning methods, learning resources, learning techniques, and learning tactics can be well controlled. Thus the implementation of the scientific approach can be implemented properly.

\section{References}

[1] D. . Kirby, "Entrepreneurship Education: Can Business Schools Meet the Chalange," J. Int. Soc. Res., vol. 4, no. 1, pp. 73-93, 2005.

[2] S. Košir and V. A. Bezenšek, "Higher education institutions and their innovative approach to communication. Economy \& Business," vol. 3, no. 1, pp. 14-21, 2009.

[3] K. D.F, Entreprenuership Education:Emergin Trends And Challenger for The 21 Centure, The Entreprenuership Program. 2005.

[4] H. C, I. S. Wekke, and A. Cahaya, "Entrepreneurship and Education: Creating Business Awareness for Students in East Java Indonesia. Social and Behavioral Sciences," vol. 177, no. 4, pp. 459-463, 2015.

[5] [5] Winarno A, Pendidikan Kewirausahaan Berbasis Nilai. Surabaya: Putra Media Nusantara, 2005.

[6] D. [6] Morselli, M. Costa, and U. Margiotta, "Entrepreneurship education based on the Change Laboratory," Int. J. Manag. Educ., vol. 12, no. 11, pp. 333-348, 2014

[7] D. Chou, Applying design thinking method to social entrepreneurship project. 2017.

[8] D. Guardia, M. Gentile, alentina D. Grande, S. Ottaviano, and M. Allegra, "A Game based Learning Model for Entrepreneurship Education," Soc. Behav. Sci., vol. 141, no. 8, pp. 195-199, 2014. 
[9] E. Commission, "Entrepreneurship Education at School in Europe - National Strategies, Curricula and Learning Outcomes," Educ. Audiov. Cult. Exec. Agency, 2012.

[10] A. [11] Winarno, "Entrepreneurship Intention: Perspective of Personality Characteristics, Social Network Learning (study on UM Academic and Vocational Program students),” Bus. Econ. Journal, 17 March 1, pp. 67-78, 2012.

[11] J. R. [12] Cornwall and W. J. Dennis Jr, "Peeling the onion: public policy in entrepreneurship education. Journal of Entrepreneurship and Public Policy," vol. 1, no. 1, pp. 12-21, 2012.

[12] [15] Rusman, Manajemen Kurikulum. Jakarta: Rajawali Pers, 2011.

[13] [16] Rusman, Belajar dan Pembelajaran Berorientasi Standar Proses Pendidikan. Jakarta: kencana, 2017.

[1] Central Bureau of Statistics. Unemployment Rate Opened Based on Recent Education Completed As of February 1, 2017.

[2] European Commission. Entrepreneurship Education: Enabling Teachers as a Critical Success Factor. A report on Teacher Education and Training to prepare teachers for the challenge of entrepreneurship education. Brussels.

[3] Regulation of the Minister of Education and Culture of the Republic of Indonesia Number 69 of 2013 concerning the Basic Framework and Curriculum Structure of the Secondary School/ Madrasah Aliyah School 